УДК [631.526.325+635.623]:[631.559+577.1] (292.485) (1-14)

(C) 2012

Гойсюк Л. В., асистент

Подільський державний аграрно-технічний університет

\title{
ВПЛИВ СОРТУ (ГІБРИДУ) НА УРОЖАЙНІСТЬ ТА БІОХІМІЧНІ ПОКАЗНИКИ ПЛОДІВ КАБАЧКА КУЩОВОГО В УМОВАХ ПІВДЕННОЇ ЧАСТИНИ ЗАХІДНОГО ЛІСОСТЕПУ УКРАЇНИ
}

\section{Рецензент - доктор сільськогосподарських наук В. І. Овчарук}

Розглянуто питання біохімічного складу плодів кабачка кущцового сорту Чаклун та гібридів Мостра $F_{1} i$ Сангрум $F_{1}$, сівбу яких проводили в периу декаду травня за схемою розміщення рослин $70 \times 70 \mathrm{~cm}$.

Визначено і проаналізовано в плодах кабачка кущьового вміст сухої речовини, иукру, вітаміну С та нітратів. Крім того подано аналіз урожайності зазначених сорту та гібридів кабачка кущуового в умовах південної частини західного Лісостепу

України. За результатами досліджень було встановлено, щуо гібрид кабачка кущуового Сангрум $F_{1}$ виявився найбільи урожайним $(87,65$ m/2a).

Ключові слова: кабачок кущзоий, урожайність, сорт, гібрид.

Постановка проблеми. Стратегічним завданням аграрної політики України є гарантування продовольчої безпеки країни. Продовольча безпека передбачає забезпечення населення продовольством, достатнім для задоволення фізіологічних потреб людини.

Овочі займають вагоме місце 3-поміж основних продуктів харчування. Споживання овочів у 2009 р. становило 137,1 кг на одну особу. Проте цей показник занижений відповідно до встановленої за нормою МО3 України «Орієнтовний набір основної продовольчої сировини і харчових продуктів для забезпечення в середньому на душу населення на 2005-2015 рр.» раціональної норми харчування овочів і баштанних, що становить 161 кг/рік на одну особу [3].

Кабачок - найбільш розповсюджена овочева культура, що в останні роки привертає увагу завдяки іiі скоростиглості, врожайності, дієтичності та холодостійкості. Вирощування кабачка не вимагає значних затрат праці та енергоресурсів, що дозволяє розширити асортимент, покращати забезпечення населення овочевою продукцією в ранні строки [2]. Одним із важливих завдань збільшення виробництва овочевих культур, зокрема кабачка кущового, є дослідження сучасних високоврожайних сортів і гібридів зі стандартизованими якісними показниками.
Аналіз основних досліджень і публікацій, у яких започатковано розв'язання проблеми. Дослідженнями встановлено, що старі сорти кабачків, такі як Грибовський 37 і Одеський 32, мали низку недоліків. У період плодоношення їхні плоди швидко переростали й втрачали товарні якості. При цьому спостерігали низьку урожайність [5]. За результатами досліджень О. І. Улянич встановлено, що саме сучасні гібриди зарубіжної селекції (Кавілі $\mathrm{F}_{1}$, Іскандер $\mathrm{F}_{1}$ ) характеризувалися підвищеними показниками раннього урожаю та містили більшу кількість сухої речовини, цукрів і вітаміну С порівняно 3 плодами сорту Грибовський 37 [6].

Мета і завдання досліджень. В умовах південної частини західного Лісостепу України відсутні дані стосовно вирощування нових сортів і гібридів кабачка кущового. Тому метою досліджень було вивчити продуктивність, визначити біохімічні показники плодів сорту та гібридів кабачка кущового.

Завданням дослідження було встановити найбільш продуктивний сорт (гібрид) кабачка кущового з високими якісними показниками.

Матеріали і методи досліджень. Науководослідна робота проводилася на базі дослідного поля кафедри плодоовочівництва лісового і садово-паркового господарства Подільського державного аграрно-технічного університету впродовж 2009-2011 років згідно 3 «Методикою дослідної справи в овочівництві та баштанництві» [4]. Для дослідження вибрали сорт кабачка кущового Чаклун і гібриди - Мостра $\mathrm{F}_{1}$, Сангрум $\mathrm{F}_{1}$. Сорт Чаклун виступав контролем. Сівбу проводили в першу декаду травня за схемою розміщення рослин 70x70 см. Збирали урожай кабачків згідно ДСТ України 318-91 «Кабачки свіжі. Технічні умови» [1]. Вміст сухої речовини у плодах визначали методом висушування наважки за температури $105^{\circ} \mathrm{C}$; вітамін $\mathrm{C}$ - за методикою Муррі; нітрати - іоноселективним методом; цукор - за методом Бертрана. 
СТОРІНКА МОЛОДОГО ВЧЕНОГО

1. Вплив сорту (гібриду) на якісні показники кабачка кущового (середнє за 2009-2011 рр.)

\begin{tabular}{|c|c|c|c|}
\hline \multirow{2}{*}{ Показник } & \multicolumn{3}{|c|}{ Сорт (гібриди) } \\
\cline { 2 - 4 } & Чаклун $(\mathrm{St})$ & Мостра $\mathrm{F}_{1}$ & Сангрум $\mathrm{F}_{1}$ \\
\hline Вміст сухої речовини, \% & 3,60 & 3,22 & 3,31 \\
\hline Вміст цукру, \% & 2,81 & 3,00 & 3,10 \\
\hline Вміст вітаміну С, мг/\% & 12,25 & 9,54 & 12,06 \\
\hline $\mathrm{N}-\mathrm{NO}_{3}, \mathrm{Mг} / \mathrm{\kappa г}$ & 251,70 & 264,22 & 279,16 \\
\hline
\end{tabular}

2. Урожайність кабачка кущового залежно від сорту (гібриду), $m / 2 a$

\begin{tabular}{|c|c|c|c|c|c|c|}
\hline \multirow[b]{2}{*}{ Сорт/гібрид } & \multirow{2}{*}{$\begin{array}{c}\text { Урожай плодів за } \\
\text { першу декаду збору } \\
\text { (середнє } \\
\text { за 2009-2011рр.) }\end{array}$} & \multicolumn{3}{|c|}{ Загальна урожайність } & \multirow[b]{2}{*}{$\mid \begin{array}{c}\text { Середнє за } \\
\text { 2009-2011 pp. }\end{array}$} & \multirow[b]{2}{*}{$\begin{array}{c} \pm \text { до } \\
\text { контролю }\end{array}$} \\
\hline & & 2009 p. & $2010 \mathrm{p}$. & $2011 \mathrm{p}$. & & \\
\hline Чаклун (контроль) & 1,98 & 56,30 & 44,60 & 113,47 & 71,45 & - \\
\hline Мостра $F_{1}$ & 0,77 & 59,70 & 62,83 & 91,26 & 71,26 & $-0,19$ \\
\hline Сангрум $\mathrm{F}_{1}$ & 1,74 & 79,30 & 86,88 & 96,77 & 87,65 & 16,20 \\
\hline HIP $_{0,95}$ & & 8,78 & 8,98 & 9,82 & & \\
\hline
\end{tabular}

Результати досліджень. За результатами досліджень встановлено (табл. 1), що в південній частині західного Лісостепу України в середньому за 2009-2011 рр. найвищий показник вмісту сухої речовини плодів кабачка кущового відмічено на контрольному варіанті (тобто, у сорту Чаклун). Він складав 3,60 \%, що на 0,38 \% більше, порівняно 3 гібридом Мостра $\mathrm{F}_{1}$, i на $0,29 \%$ - із гібридом Сангрум $\mathrm{F}_{1}$.

Проте гібриди відзначилися більшим вмістом загального цукру, що є досить суттєвим у процесі консервування. Так, максимальне значення вмісту цукру було відмічено у гібриду Сангрум $\mathrm{F}_{1}-3,10 \%$, що на $0,29 \%$ більше за контроль. Окрім того варто відзначити показник вмісту в плодах вітаміну С. Найбільша його кількість була визначена у сорту Чаклун - 12,25 мг\%, а найменша - у гібриду Мостра $\mathrm{F}_{1}(9,54$ мг\%), що на 2,71 мг\% менше контрольного показника. За період проведення досліджень вміст нітратів у плодах кабачка кущового на досліджуваних сорті й гібридах не перевищував гранично допустимого рівня (400 мг/кг для відкритого грунту). Однак, найбільшим він був у гібриду Сангрум $\mathrm{F}_{1}$ (279,16 мг/кг), що на 27,46 мг/кг більше за контроль.

Таким чином, гібрид Сангрум $\mathrm{F}_{1}$ виявився найкращим за вмістом цукру $(3,10 \%)$, а сорт Чаклун, який виступав контролем, характеризу-

\section{БІБЛІОГРАФІЯ}

1. Кабачки свежие. Технические условия: ДСТ Украины 318-91. - [Введен в действие от 21.10.91]. - К. : Госстандарт Украины, 1991. 9 c. - ( Государственный стандарт Украины). вався найвищими показниками вмісту сухої речовини $(3,60 \%)$ та вітаміну С $(12,25$ мг/\%) i найнижчим вмістом нітратів $(251,70$ мг/кг).

Показник урожайності кабачка кущового залежно від сорту (гібриду) також суттєво змінювався (табл. 2). Встановлено, що в середньому за три роки досліджень найменший урожай плодів за першу декаду збору $(0,77$ т/га) відмічено у гібриду Мостра $\mathrm{F}_{1}$, що на 1,21 т/га менше за контроль. Загальна урожайність при цьому також була найменшою $(71,26$ т/га), що на 0,19 т/га менше за контроль.

Щодо гібриду Сангрум $\mathrm{F}_{1}$, то урожай плодів за першу декаду збору був на рівні 1,74 т/га, що також на 0,24 т/га менше за контрольний варіант. Проте загальна урожайність була найбільшою і дорівнювала 87,65 т/га; приріст до контролю становив, відповідно, 16,20 т/га.

Отже, за результатами досліджень встановлено, що найбільша загальна урожайність досліджуваного сорту й гібридів кабачка кущового була встановлена у гібриду Сангрум $\mathrm{F}_{1}(87,65$ т/га).

Висновки. Дослідженнями встановлено, що в умовах південної частини західного Лісостепу України найбільш урожайним серед вивчених сорту та гібридів кабачка кущового було відмічено гібрид Сангрум $\mathrm{F}_{1}$, що забезпечував найвищий вміст загального цукру $(3,10 \%)$ i найбільшу загальну урожайність $(87,65$ т/га).

2. Катаєва T. $\epsilon$. Ранньостиглий гетерозисний гібрид кабачка Престиж F1 / Т. Є. Катаєва // Bicник Донецького національного університету. 2009. - Вип. 1. - С. 573-574. 
3. Комплексна програма підтримки розвитку українського села на період до 2015 року (проект) // Економіка АПК. - 2007. - №1 . - С. 3-50. 4. Методика дослідної справи в овочівництві і баштанництві / за ред. Г. Л. Бондаренка, К. І. Яковенка. - [3-е вид.]. - Х. : Основа, 2001. - 369 с.

5. Слепиов Ю. Плод для икры. Выбираем сорт кабачка / Ю. Слепцов// Овощеводство. - 2011. -
№6. - C. 57.

6. Улянич O. I. Урожайність та якісні показники кабачка залежно від сорту, гібриду / О. І. Улянич, 3. І. Ковтунюк, Л. І. Кузьменко // Збірник наукових праць Уманського національного університету садівництва. Основи біологічного рослинництва в сучасному землеробстві. - 2011. C. 404-407. 